УДК 631.36

(С) Л.Ю. Забродоцька, к.т.н., В.Л. Петров, Р.В. Кірчук, к.т.н. Луцький національний технічний університет

А.В. Хомич

Любешівський технічний коледж Луцького національний технічний університет

\title{
ВДОСКОНАЛЕННЯ СУШАРКИ НАСІННЯ РІПАКУ
}

У статті наведено огляд методів та засобів сушіння ріпакового насіння. Обтрунтовано доцільність модернізації існуючих сушарок механічними системами перемішування шару зерна. Запропоновано схему сушарки, що дозволяє суттєво 
зменшити енерговитрати на процес сушіння дрібнодисперсних сільськогосподарських рослинних матеріалів.

\section{РІПАК, СУШАРКА, ПРОЦЕС СУШІННЯ, ШНЕК, ШАР МАТЕРІАЛУ, ЕНЕРГОЗБЕРЕЖЕННЯ}

Постановка проблеми. Завершальним і важливим етапом у вирощуванні ріпаку $є$ ретельне проведення збиральних робіт, організація проміжного складування та доочищення зібраного врожаю, а за потреби - сушіння товарного зерна. Як і інші культури, ріпак має свої специфічні особливості, які обов'язково враховують під час організації вищеназваних технологічних процесів. Запізнення або неправильне проведення комбайнування, доочищення і зберігання може призвести до значних матеріальних збитків.

Ріпак після збирання часто має підвищену забрудненість та вологість. Тому рекомендується його швидке доочищення i досушування. Використовують очисні машини різних типів, але 3 набором потрібних решет. Добре працюють стаціонарні зерноочищувальні агрегати типу 3АВ-20, 3АВ-40 та пересувні повітряно-решетні машини ОВС-25, ОВП-20А тощо. Гранично допустимі строки проміжного зберігання недоочищеного $\mathrm{i}$ очищеного насіння значно різняться, тому і слід враховувати це на практиці [1].

Сушіння товарного ріпаку проводять сушарками різних конструкцій та типів. Базисною для ріпаку є вологість 8-10\%. Післязбиральний обробіток, зокрема сушіння, - дуже енерговитратний процес, що потребує вивчення та вдосконалення.

Аналіз останніх досліджень і публікацій. Якщо вологість насіння ріпаку перевищує 8\%, його краще спрямовувати на досушування. Сушіння виконують за певної температури залежно від стану, вологості і призначення зерна та конструкції сушарки. Товарний ріпак (продовольче, кормове і технічне насіння) за вологості до 13\% рекомендовано висушувати в шахтних прямоточних сушарках за температури теплоносія $80 \ldots 90^{\circ} \mathrm{C}$ та нагрівання насіннєвої маси до $50^{\circ} \mathrm{C}$. За вологості понад $13 \%$ температуру теплоносія знижують на $10 \ldots 20^{\circ} \mathrm{C}$, а нагрівання зерна - на $5 \ldots 10^{\circ} \mathrm{C}$. У сушарках без перемішування насіння температуру теплоносія витримують на рівні $60^{\circ} \mathrm{C}$. Насіннєвий ріпак висушують, враховуючи поточну вологість зерна і знижуючи температуру мірою підвищення збиральної вологості [2].

Порівняно невеликі об'єми ріпаку можна висушити в сушарках камерного типу чи подовими, обладнаними підігрівачами повітря, теплогенераторами. В цих сушарках сушіння виконується в 
нерухомому шарі, тому температура теплоносія має становити $40 \ldots 50$, а нагрівання зерна - не вище $30 \ldots 35^{\circ} \mathrm{C}$ залежно від його вологості, висота насіннєвого шару — до 30 см [2].

У господарствах, які не мають власних сушарок, насіння досушують за сонячної погоди на відкритих майданчиках (шар насіння завтовшки 5-10 см) за регулярного перемішування. Однак цей спосіб надто ризикований і тривалий, тому слід надавати перевагу застосуванню сушарок

Аналізуючи відомі дослідження процесу сушіння ріпакового насіння можна узагальнити такі вимоги [2-8]:

- слід максимально герметизувати сушарку в місцях руху та можливого просипання насіння;

- вологість насіння після сушіння не має бути нижчою ніж 6\%, оскільки за нижчого їі рівня різко зростає насіннєве травмування;

- максимальне зняття вологості за один прохід насіння через сушарку становить 5-6\%;

- насіння після сушіння охолоджують до температури, яка не перевищує зовнішню більш ніж на $5^{\circ} \mathrm{C}$.

Для сушіння бажано використовувати зерносушарки, в яких теплоносієм є чисте атмосферне повітря, підігріте до потрібної температури.

Однак у літературі мало уваги приділено дослідженням, що стосуються інтенсифікації процесу сушіння внаслідок перемішування шару сипкого матеріалу та аналізу впливу структури шару ріпакового насіння на перебіг процесу його зневоднення.

Мета дослідження - дослідити особливості кінетики сушіння ріпакового насіння та виробити рекомендації щодо вдосконалення існуючих сушарок, шляхом встановлення у сушильних камерах шнекових перемішувачів шару зерна.

Результати дослідження. Для проектування нових або ж вдосконалення існуючих сушарок дрібнодисперсних сільськогосподарських рослинних матеріалів необхідно встановити характер перебігу кінетики процесу сушіння конкретного насіннєвого матеріалу. Тому були проведені дослідження процесу сушіння ріпакового насіння в лабораторних умовах. Вологість проб встановлювалась методом зважування проб та їх повним висушуванням.

Для дослідження процесу сушіння насіння ріпаку використовувалась розроблена лабораторна установка (рис.1). Установка складається 3 вентилятора, калорифера, гнучкого з’єднання, сушильної камери з касетами для матеріалу. Атмосферне 
повітря подається вентилятором до калорифера, нагрівається до температури, встановленої регулятором i гнучким 3'єднанням подається до сушильної камери, в якій встановлені пронумеровані касети з пробами одна над одною. Сушильний агент рухається крізь встановлені в зазначеній послідовності касети з пробами насіння ріпаку знизу вверх.

Для сушіння у касети засипалися проби матеріалу 3 відомою початковою вологістю і масою.

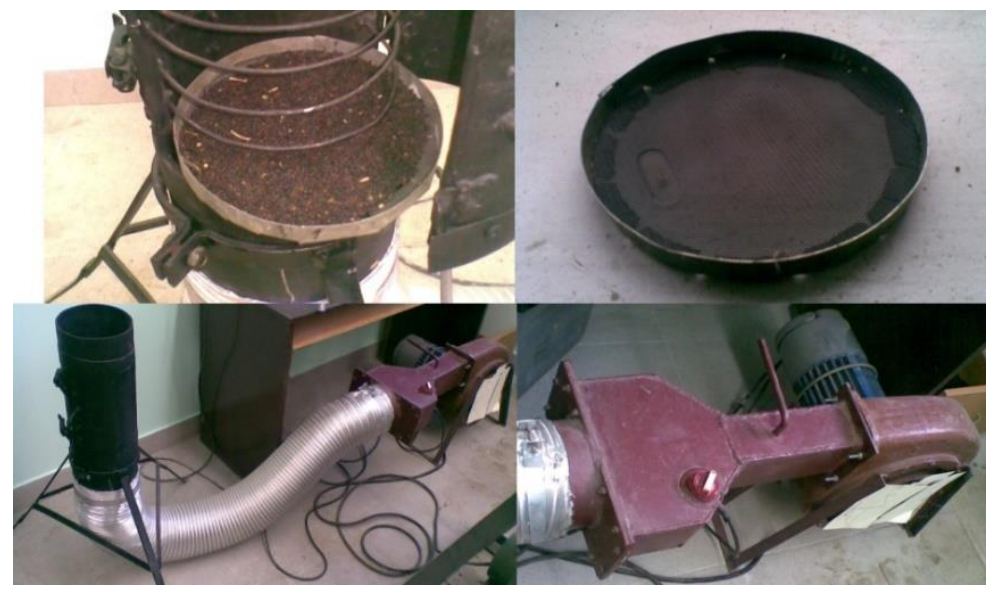

Рис. 1 - Установка для дослідження процесу сушіння насіння ріпаку

Сушіння проводилось для початкової відносної вологості матеріалу $11 \%$ і $15,5 \%$ при температурі нагрітого повітря $60-65^{\circ} \mathrm{C}$ i $45-50^{\circ} \mathrm{C}$ відповідно. Через однакові проміжки часу фіксувались значення маси в кожній касеті, за якими було визначено вологість i побудовано графіки зміни вологості з часом (рис.2.).

Загалом, у господарства для зневоднення не надто значних об’ємів насіннєвого матеріалу часто застосовуються фермерські сушарки (рис.3) типу AGRIMEC серії AS (Італія). 

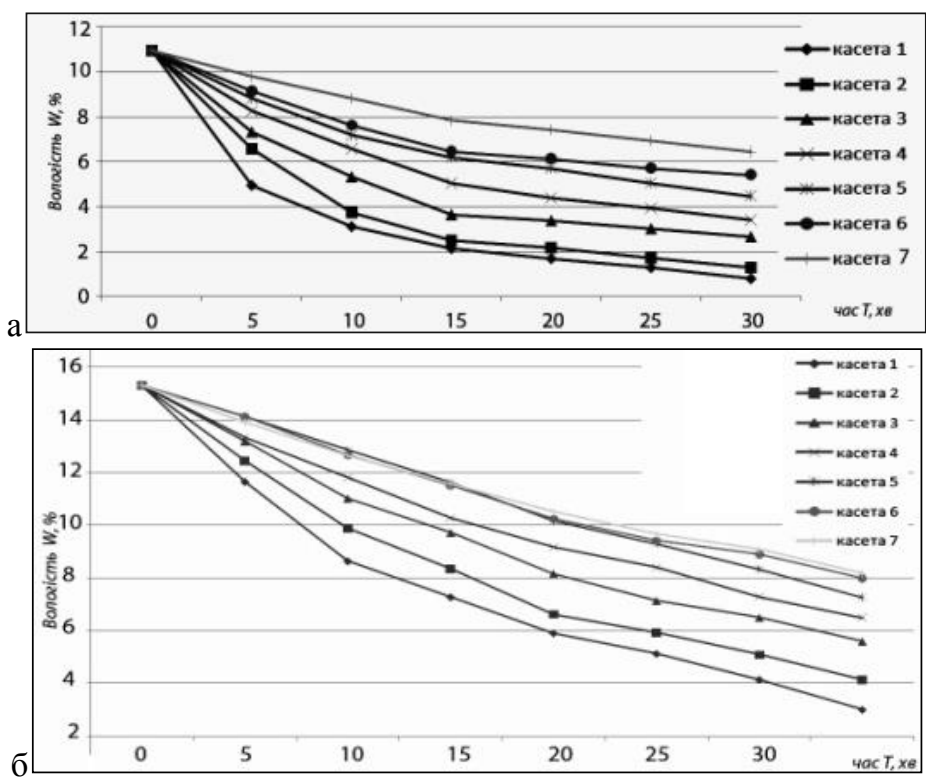

Рис. 2 - Зміна вологості насіння ріпаку (а) 3 початковою вологістю

$11 \%$ і температурою сушильного агенту $60-65^{\circ} \mathrm{C}$ та (б) 3 початковою вологістю $15,5 \%$ і температурою сушильного агенту $45-50^{\circ} \mathrm{C}$

Такі сушарки, а їх ще називають циркуляційними, мають місткість $12 \ldots 1,7 \mathrm{~m}^{3}$. Вони зручно транспортуються, у їхню комплектацію входять також ситовий очисник зерна та приймальний бункер. Поверхневі сита корпуса сушарки і камери згоряння виконані в оцинкованому варіанті i покриті шаром термореактивного поліефіру. Газові пальники оснащені випарниками газу. Це дозволяє застосовувати зріджений пропанбутан і експлуатувати сушарки при низьких значеннях температури, що особливо важливо при сушінні насіннєвого зерна. Сушарки можуть бути оснащені теплогенераторами, які працюють на грубному чи дизельному паливі з тепловою потужністю від 75 до 760 кВт, та подають чисте підігріте повітря (без домішок продуктів спалювання палива).

Вказані вище зерносушарки відносяться до так званих мобільних (пересувних) сушарок, які широко використовуються за кордоном для сушіння матеріалу у невеликих фермерських господарствах. 3'явився до них інтерес і в Україні з боку агрофірм і пересувних механізованих загонів, які прагнуть збільшити період 
використання комбайнів, переміщаючи їх з півдня на північ. Адже на первинну обробку і зберігання зібраного зерна приходиться більше $25 \%$ від загальних витрат на його виробництво. Тому використання порівняно недорогих пересувних зерносушарок, здатних працювати в будь-якому місці за будь-яких погодних умов - це реальний шлях підвищення ефективності виробництва зернових, бобових і олійних культур $[9,10]$.

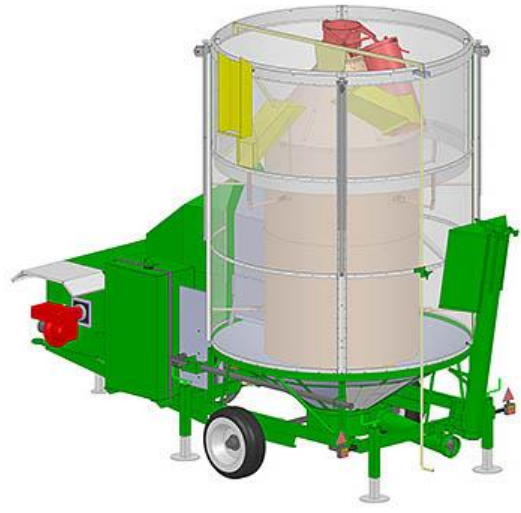

Рис.3 - Сушарка AGRIMEC серії AS (Італія)

Одним 3 напрямків підвищення енергоефективності та інтенсифікації процесу сушіння ріпакового зерна $\epsilon$ його перемішування у сушильній камері. Основною перевагою такого методу сушіння $\epsilon$ руйнування повітряних каналів 3 малим аеродинамічним опором, через які проходить більша частина сушильного агенту i, відповідно, зменшується час теплової обробки. Основними технологічними перевагами розрихленого шару $є$ висока інтенсивність процесів переносу теплоти та пов'язані 3 цим низькі перепади температур всередині самого шару. Рух сушильного агенту в такому шарі зерна прискорює перенесення вологи із самих зернівок до поверхні. Це сприяє прискоренню сушіння.

Добре себе зарекомендували у якості робочих органів шнекові перемішувачі. Такі, наприклад, застосовуються у мобільній сушарці TURBODAN TD-15 MODILDRIER (Німеччина). Ці робочі органи перемішують і розпушують шар зерна, що знаходиться у причепі-сушарці (рис.4). 


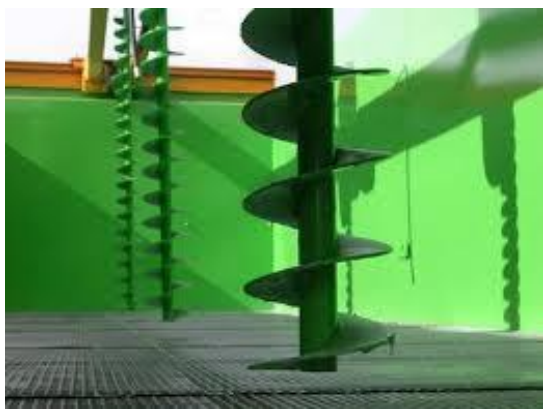

Рис.4 - Шнекові

перемішувачі шару зерна у сушарці TURBODAN TD-15

Зважаючи на отримані експериментальні результати та аналізуючи досвід лідерів рику сушарок можна запропонувати встановлювати систему механічних перемішувачів і розпушувачів шару зернового матеріалу у сушильну камеру сушарки. Така система являє собою вертикально розміщені шнекові робочі органи, які перемішують шар зерна почергово піднімаючи його та опускаючи (рис.5).

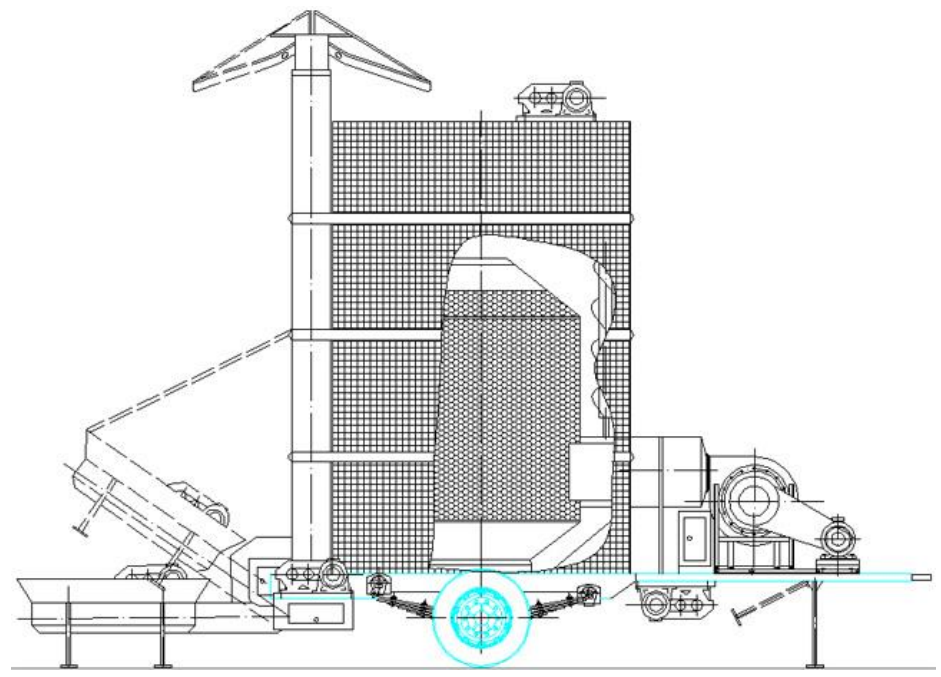

Рис.5 - Сушарка із механічною системою перемішування зерна у сушильній камері

Дослідження процесу сушіння сільськогосподарських матеріалів 3 їх одночасним перемішування $\mathrm{i}$ розпушування 
представлено у роботі [11]. Заслуговує на увагу методика визначення енерговитрат на привод спіралеподібних робочих органів, що розпушують шар насіння. Такий же підхід може бути використаний і для аналізу сушарки 3 шнековими перемішуючими робочими органами. Зокрема, для забезпечення технологічного процесу роботи сушарки затрачається енергія:

- на формування сушильного агента, шляхом нагрівання атмосферного повітря електрокалорифером або в результаті згоряння пального;

- $\quad$ на створення тиску у повітропроводах і сушильній камері за допомогою вентилятора;

- $\quad$ на перемішування і розпушування матеріалу, що піддається сушінню;

- на роботу завантажувальних і вивантажувальних пристроїв.

Розрахунок і порівняння витрат на додаткові операції дозволяє зробити висновок щодо доцільності використання механічної системи перемішування шару зерна в процесі сушіння.

Виходячи 3 тривалості перебування матеріалу в сушильній камері $\tau$, хв. і маси матеріалу $m$, що заповнює сушильну камеру, продуктивність $P$ сушарки визначається за залежністю:

$$
P=\frac{m \cdot 60}{T \cdot 1000}, \text { т/год. }
$$

Маса висушеного за 1 годину матеріалу визначиться за формулою [11]:

$$
P^{\prime}=P \cdot \frac{100-w_{1}}{100-w_{2}},
$$

де $P$ - маса вологого матеріалу, т;

$P^{\prime}$ - маса сухого матеріалу, т;

$w_{1}$ - початкова відносна вологість, \%;

$w_{2}$ - кінцева відносна вологість, \%.

У випадку застосування електрокалорифера для нагрівання повітря годинна витрата електроенергії для насіння для заданих параметрів сушіння визначається за формулою:

$$
N_{k}=\frac{\Delta I \cdot L}{\eta_{e} \cdot 859,845, \mathrm{\kappa BT}}
$$

де $\eta_{k}-$ ККД калорифера;

$L$ - годинна витрата повітря, кг с.п./кг в.в;

$\Delta I$ - різниця тепловмісту, ккал/г с.п. 
В процесі перемішування i розпушування матеріалу робочими органами затрачається потужність на подолання опору матеріалу.

Потужність, яка затрачається на приведення в дію одного робочого органу, наближено визначимо за формулою [11]:

$$
N_{. .}=47 \cdot g \cdot \psi \cdot D_{s}^{2} \cdot k_{s} \cdot v_{s} \cdot \rho \cdot k^{\prime} \cdot c \cdot L_{c} \cdot \omega k_{3} \cdot 10^{-3}
$$

де $\psi$ - коефіцієнт $(\psi=0,3 . .0,4)$;

$D_{s}$ - діаметр спіралі, м;

$k_{s .}-$ крок спіралі, м;

$v_{s}$ - частота обертання, хв. ${ }^{-1}$;

$\rho_{c}-$ об'ємна маса матеріалу, кг/м³

$k$ ' - коефіцієнт, що залежить від властивостей матеріалу (для легко сипких матеріалів $\left.k^{\prime}=0,75 . .1,0\right)$;

$c$ - коефіцієнт, що враховує нахил робочого органа;

$L_{c}$ - довжина робочого органа, м;

$\omega-$ коефіцієнт опору руху $(\omega=4 . .5)$;

$k_{3}$ - коефіцієнт запасу потужності $\left(k_{3}=1,2 . .1,25\right)$.

Тоді загальна потужність для всіх робочих органів

$$
N_{\text {p.о.заг. }}=N_{\text {p.o. }} \cdot m
$$

де, $m$ - кількість робочих органів.

Необхідна потужність електродвигуна 3 врахуванням ККД привода визначиться за формулою:

$$
N_{\text {дв. }}=N_{\text {p.. заг }} / \eta_{n p}
$$

де $\eta_{n p}-$ ККД приводу.

Потужність $N$ (кВт·год) електродвигуна вентилятора:

$$
N_{s}=\frac{Q_{s} \cdot P_{s}}{3600 \cdot 1000 \cdot \eta_{6} \cdot \eta_{n} \cdot \eta_{\kappa}},
$$

де $Q_{B}$ - кількість агента сушіння, що подається вентилятором, $\mathrm{M}^{3} /$ год;

$P_{B}-$ повний тиск, який розвивається вентилятором під час роботи сушарки, Па;

$\eta_{6}$ - ККД вентилятора $\left(\eta_{6}=0,7\right)$;

$\eta_{n}=0,97$ - ККД пасової передачі;

$\eta_{\kappa}=0,9$ - ККД , яким враховують втрату в підшипниках.

Вказані додаткові енерговитрати компенсуються зменшенням часу сушіння насіннєвого матеріалу, за рахунок чого i передбачається ефект енергозбереження. 
Висновоки. $\mathrm{y}$ роботі представлено теоретичне узагальнення існуючих технологій сушіння ріпакового насіння $\mathrm{i}$ запропоновано нове рішення, що полягає у вдосконаленні технологічного процесу сушіння насіння ріпаку за рахунок інтенсифікації сушіння шляхом розпушування і перемішування шару матеріалу у сушильній камері сушарки. Необхідність розпушування i перемішування дисперсного сільськогосподарського матеріалу, зокрема насіння ріпаку, в процесі сушіння підтверджена в результаті аналізу.

Застосування запропонованої конструкції камери сушіння, а також методів розрахунку іiі параметрів, дозволить суттєво зменшити енергозатрати загалом.

\section{Література}

1. Ріпак: особливості збирання, сушіння та зберігання врожаю [Електронний ресурс] / А. Шіхерт // Пропозиція - Головний журнал з питань агробізнесу - Режим доступу до журн.:

https://propozitsiya.com/ua/ripak-osoblivosti-zbirannya-sushinnya-tazberigannya-vrozhayu.

2. Збирання та збереження ріпаку[Електронний ресурс] / М. Кирпа// Спецвипуск ж. Пропозиція. Озимий ріпак від А до Я/ 201. - С.- 16-48 - Режим доступу до журн.:

https://propozitsiya.com/ua/zbirannya-ta-zberezhennya-ripaku

3. Птицын С.Д. Зерносушилки.- М.: Машиностроение, 1966, 180 c.

4. Герой А.П., Самочетов В.Ф. Зерносушение и зерносушилки. М.: Колос, 1967.

5. Рагулин М.С. Очистка, сушка и хранение - М.: Россильхозиздат, 1980. - 160 с., ил.

6. Зеленко В.И. Конвективная сушка сельскохозяйственных материалов в плотном слое. Основы теории.-Тверское областное книжно-журнальное издательство, 1998. -96с.

7. Жидко В. И. Лабораторный практикум по зерносушению. M., 1983.

8. Остапчук Н.В. и др. Повышение эффективности сушки зерна/ Н.В. Остапчук, А.Б. Шашкин, В.Д. Каминский - К. Урожай. 1988.136с., ил.

9. Лебедев П.Д. Расчёт и проектирование сушильных установок. 1962.- 320 с. ил.

10. Станкевич Г.М. Техніка та технологія сушіння зерна у фермерських господарствах/ Станкевич Г.М.// Зернові продукти і комбікорми № 3 (43), 2011- 9-13с. 
11. Станкевич Г.М. Сушіння зерна: Підручник / Г.М. Станкевич, Т.В. Страхова, В.І. Атаназевич. - К.: Либідь, 1997. - 320 с

12. Ящук А.А. Обгрунтування параметрів сушарки насіння льону олійного : автореф. дис. ... канд. техн. наук : 05.05.11/ А.А. Ящук; - Кіровоград, 2014. - 20 с 